\title{
Blunting senescence boosts liver regeneration
}

\author{
Jodie Birch $^{1,2}$ and Jesus Gil ${ }^{1,2}$ \\ ${ }^{1}$ MRC London Institute of Medical Sciences, London W12 0NN, United Kingdom; ${ }^{2}$ Institute of Clinical Sciences, Faculty of \\ Medicine, Imperial College London, London W12 0NN, United Kingdom
}

The mammalian liver possesses a unique capacity for regeneration. However, this regenerative potential declines with age due to unknown mechanisms. In this issue of Genes \& Development, Ritschka and colleagues (pp. 489-494). compare liver regeneration upon partial hepatectomy in young and adult mice. Partial hepatectomy causes a transient increase in $\mathbf{p} 21$ in a subpopulation of hepatocytes that persists in adult mice. Remarkably, treatment with the BCL-2 family inhibitor ABT-737 blunts p21 expression, enhancing liver regeneration.

Cellular senescence is a stress response that causes a stable cell cycle arrest and is accompanied by distinct changes, including genetic, metabolic, and morphological alterations. Senescence prevents the replication of damaged cells. The growth arrest associated with senescence is mediated by induction of the cyclin-dependent kinase (CDK) inhibitors $\mathrm{p} 21^{\text {Cip1 }}$ and $\mathrm{p} 16^{\text {Ink4a }}$ (Herranz and Gil 2018). The value of a controlled, well-regulated senescence program is offset by the accruing evidence that the aberrant accumulation of senescent cells promotes aging and related disorders. Indeed, a hallmark feature of senescent cells is the enhanced production of soluble signaling molecules; the so-called senescence-associated secretory phenotype (SASP), which mediates many of the consequences of senescence, including those that are detrimental (McHugh and Gil 2018). While parallels between senescence and aging have long been reported, a causative role for senescence in aging was provided by the observation that the genetic removal of $\mathrm{p} 16^{\text {Ink4a }}$ positive cells increased life span and delayed age-related disorders in mice (Baker et al. 2016). This observation has fuelled research into identifying molecules, termed "senolytics," that exploit vulnerabilities of senescent cells in order to trigger their demise (Zhu et al. 2015). The therapeutic potential of senolysis has been demonstrated in pathologies as diverse as cardiovascular dysfunction, liver steatosis (Ogrodnik et al. 2017), and neurodegeneration (Bussian et al. 2018).

[Keywords: senescence; senolytic; liver regeneration; $\mathrm{p} 21 ; \mathrm{p} 16^{\text {Ink4a }} ; \mathrm{ABT}$ 737; hepatocyte; aging]

Corresponding author: jesus.gil@imperial.ac.uk

Article is online at http://www.genesdev.org/cgi/doi/10.1101/gad.337394. 120 .
Senescence has been linked to impaired regeneration following severe liver injury (Krizhanovsky et al. 2008; Bird et al. 2018). However, whether senescence is causally involved in age-associated loss of regenerative capacity in the liver remains unclear. Ritschka et al. (2020) aimed to unravel the link between senescence and regenerative decline using partial hepatectomy (PH). $\mathrm{PH}$ in adult (6- to 8-mo-old) animals was associated with delayed regeneration and lipid accumulation, in stark contrast to young (2- to 3-mo-old) mice, which showed an almost complete recovery $7 \mathrm{~d}$ after $\mathrm{PH}$. In young and adult livers, the expression of $\mathrm{p} 21$ peaked in a subset of hepatocytes $24-48 \mathrm{~h}$ after surgery. Interestingly, p21 levels remained aberrantly high in the adult liver. The p21-positive hepatocytes did not express other senescence markers, such as $\mathrm{p} 16^{\text {Ink4a }}$, suggesting that these cells were not fully senescent. Nevertheless, cytokine profiling revealed elevated levels of SASP factors, including IGFBP-3, CCL2, and MMP2, $3 \mathrm{~d}$ after PH in adult livers. To target the senescence response, researchers administered the senolytic ABT-737 prior to surgery. Compared with vehicle-treated mice, those receiving ABT737 showed augmented regenerative capacity and improved liver function, evidenced by increased organ weight and normalized serum liver enzymes. Additionally, the lipidosis that emerged following $\mathrm{PH}$ in older animals was minimized by ABT-737. At the cellular level, ABT-737 decreased p21 transcript and protein levels, reducing p21positive hepatocyte burden after injury. Intriguingly, p16 ${ }^{\text {Ink4a }}$ was not affected by ABT-737 despite increasing in adult livers prehepatectomy and being a key marker of senescent cells. Indeed, p16 $6^{\text {Ink } 4 a}$ levels were not increased further following $\mathrm{PH}$ and, unlike p21, cells expressing high levels of $\mathrm{p} 16^{\text {Ink4a }}$ were not hepatocytes but macrophages and endothelial cells. Similarly, while a transient increase in expression of the $\mathrm{p} 53$ activator $\mathrm{p} 19^{\text {Arf }}$ was observed after injury, no differences were found between young and adult mice, and ABT-737 did not affect p19 Arf levels. This highlights the dynamic changes in senescence-associated genes in the immediate aftermath of $\mathrm{PH}$ and suggests

(C) 2020 Birch and Gil This article is distributed exclusively by Cold Spring Harbor Laboratory Press for the first six months after the full-issue publication date (see http://genesdev.cshlp.org/site/misc/terms.xhtml). After six months, it is available under a Creative Commons License (Attribution-NonCommercial 4.0 International), as described at http://creativecommons.org/licenses/by-nc/4.0/. 
that the benefits of ABT-737 are likely due to interference with the p21-positive hepatocyte population. This idea is strengthened by the observation that adult p21-deficient mice experienced increased regeneration following $\mathrm{PH}$ in the short term, whereas $\mathrm{p} 16^{\text {Ink4a }}$ and $19^{\text {Arf }}$ deficiency provided no such advantage. Excitingly, a number of SASP-associated cytokines that were elevated in the adult liver after surgery were dampened by ABT-737, suggesting that the senescence-weakening effects of the compound extend to the associated SASP-like milieu (Fig. 1).

The results described by Ritschka et al. (2020) corroborate past studies demonstrating that hepatocyte and nonparenchymal cell senescence occurs following acute liver damage, leading to impaired regeneration (Krizhanovsky et al. 2008; Bird et al. 2018). An intriguing finding of this study is that the cells most likely to be contributing to defective regeneration in the adult liver (namely, hepatocytes that aberrantly express $\mathrm{p} 21$ ) are not yet fully-fledged senescent cells but may represent an intermediate senescent state. Still, administration of a senolytic compound was able to enhance liver regrowth and function in adulthood. This outcome was attributed to the ability of ABT737 to modify presenescent cellular changes. Indeed, Ritschka et al. (2020) failed to detect apoptosis following ABT-737 administration, but instead showed a decrease in the expression of $\mathrm{p} 21$ and SASP factors. These findings suggest that a so-called senolytic compound, such as ABT-737, could be exerting its effects at least in part by blunting senescence. How ABT-737 inhibits 21 and associated inflammatory processes in this setting remains to be determined. Regardless of the mechanism, the compelling finding that senotherapy releases the breaks on rejuvenation in adulthood warrants further exploration. This study also emphasizes the complexity of the senescence

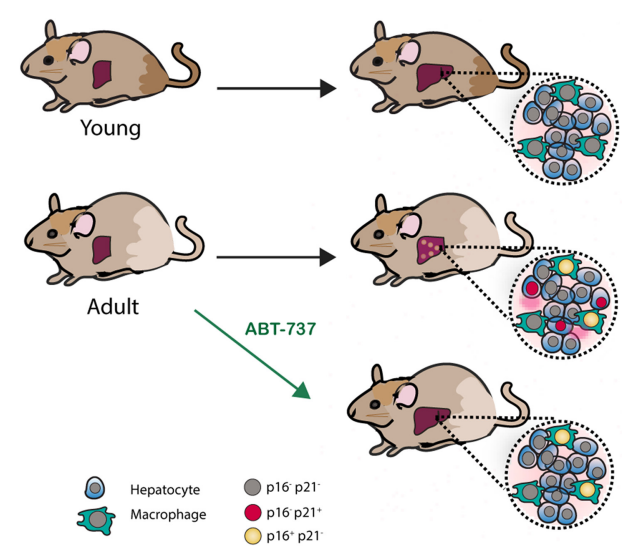

Figure 1. Treatment with ABT-737 improves liver function and promotes regeneration. Adult mice show impaired liver regeneration following partial hepatectomy (PH). A population of p16-positive macrophages is present in the livers of adult mice. Following injury, a subpopulation of hepatocytes expressing aberrant levels of p21 persists in the livers of adult but not young mice. Pretreatment with the senolytic compound ABT-737 improves liver regeneration and function in adults. ABT-737 inhibits $\mathrm{p} 21$ expression in hepatocytes and reduces inflammation without affecting p16-positive liver macrophages. response, exemplified by the dynamic induction of senescence mediators following $\mathrm{PH}$, and by the observation that senolytic treatment did not have an impact on p16 ${ }^{\text {Ink4a }}$-positive cells. This is in contrast to previous work demonstrating that elimination of $\mathrm{p} 16^{\text {Ink4a }}$-expressing cells ameliorates age- and diet-induced liver steatosis (Ogrodnik et al. 2017). In fact, during PH, p16 $6^{\text {Ink4a }}$ deficiency led to poorer regeneration. Similarly, the presence of senescent cells has been shown to limit fibrosis following liver injury (Krizhanovsky et al. 2008). The advantages of targeting senescent cells are therefore largely contextdependent and potentially precarious in nature, given that longer-term deficiency of p21 offered no regenerative edge following $\mathrm{PH}$. This reinforces the notion that senescence modulation must be exceptionally well-regulated and fine-tuned if we are to reap its therapeutic rewards and expand the exciting world of senotherapy further.

\section{Competing interest statement}

J.G. owns equity in and has acted as a consultant for Unity Biotechnology and Geras Bio. J.G. is a named inventor in a patent related to senolytic therapies.

\section{References}

Baker DJ, Childs BG, Durik M, Wijers ME, Sieben CI, Zhong J, Saltness RA, Jeganathan KB, Verzosa GC, Pezeshki A, et al. 2016. Naturally occurring p16 ${ }^{\text {Ink4a }}$-positive cells shorten healthy lifespan. Nature 530: 184-189. doi:10.1038/nature16932

Bird TG, Müller M, Boulter L, Vincent DF, Ridgway RA, LopezGuadamillas E, Lu WY, Jamieson T, Govaere O, Campbell $\mathrm{AD}$, et al. 2018. TGF $\beta$ inhibition restores a regenerative response in acute liver injury by suppressing paracrine senescence. Sci Transl Med 10: eaan1230.

Bussian TJ, Aziz A, Meyer CF, Swenson BL, van Deursen JM, Baker DJ. 2018. Clearance of senescent glial cells prevents taudependent pathology and cognitive decline. Nature 562: 578-582. doi:10.1038/s41586-018-0543-y

Herranz N, Gil J. 2018. Mechanisms and functions of cellular senescence. J Clin Invest 128: 1238-1246. doi:10.1172/JCI95148

Krizhanovsky V, Yon M, Dickins RA, Hearn S, Simon J, Miething C, Yee H, Zender L, Lowe SW. 2008. Senescence of activated stellate cells limits liver fibrosis. Cell 134: 657-667. doi:10 $.1016 /$ j.cell.2008.06.049

McHugh D, Gil J. 2018. Senescence and aging: causes, consequences, and therapeutic avenues. I Cell Biol 217: 65-77. doi:10.1083/jcb.201708092

Ogrodnik M, Miwa S, Tchkonia T, Tiniakos D, Wilson CL, Lahat A, Day CP, Burt A, Palmer A, Anstee QM, et al. 2017. Cellular senescence drives age-dependent hepatic steatosis. Nat Commun 8: 15691. doi:10.1038/ncomms15691

Ritschka B, Knauer-Meyer T, Sampaio Gonçalves D, Mas A, Plassat J-L, Durik M, Jacobs H, Pedone E, Di Vicino U, Cosma MP, Keyes W, et al. 2020. The senotherapeutic drug ABT-737 disrupts aberrant $\mathrm{p} 21$ expression to restore liver regeneration in adult mice. Genes Dev (this issue). doi:10.1101/gad.332643 .119

Zhu Y, Tchkonia T, Pirtskhalava T, Gower AC, Ding H, Giorgadze N, Palmer AK, Ikeno Y, Hubbard GB, Lenburg M, et al. 2015. The Achilles' heel of senescent cells: from transcriptome to senolytic drugs. Aging Cell 14: 644-658. doi:10 $.1111 /$ acel.12344 


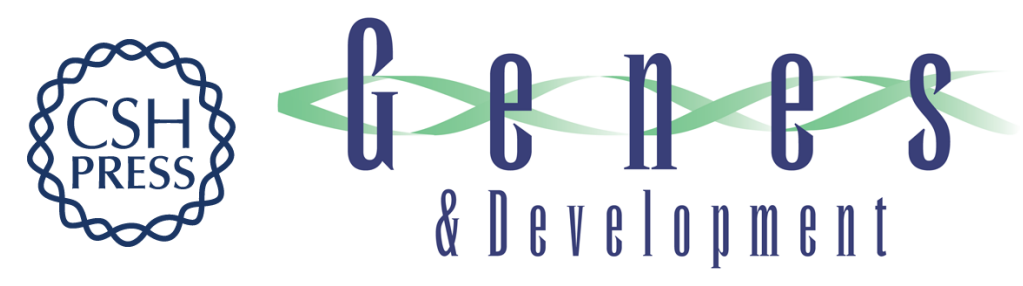

\section{Blunting senescence boosts liver regeneration}

Jodie Birch and Jesus Gil

Genes Dev. 2020, 34:

Access the most recent version at doi:10.1101/gad.337394.120

Related Content The senotherapeutic drug ABT-737 disrupts aberrant p21 expression to restore liver regeneration in adult mice

Birgit Ritschka, Tania Knauer-Meyer, Daniel Sampaio Gonçalves, et al.

Genes Dev. April , 2020 34: 489-494

References This article cites 9 articles, 3 of which can be accessed free at:

http://genesdev.cshlp.org/content/34/7-8/463.full.html\#ref-list-1

Articles cited in:

http://genesdev.cshlp.org/content/34/7-8/463.full.html\#related-urls

Creative This article is distributed exclusively by Cold Spring Harbor Laboratory Press for the first Commons License six months after the full-issue publication date (see http://genesdev.cshlp.org/site/misc/terms.xhtml). After six months, it is available under a Creative Commons License (Attribution-NonCommercial 4.0 International), as described at http://creativecommons.org/licenses/by-nc/4.0/.

Email Alerting Receive free email alerts when new articles cite this article - sign up in the box at the top Service right corner of the article or click here.

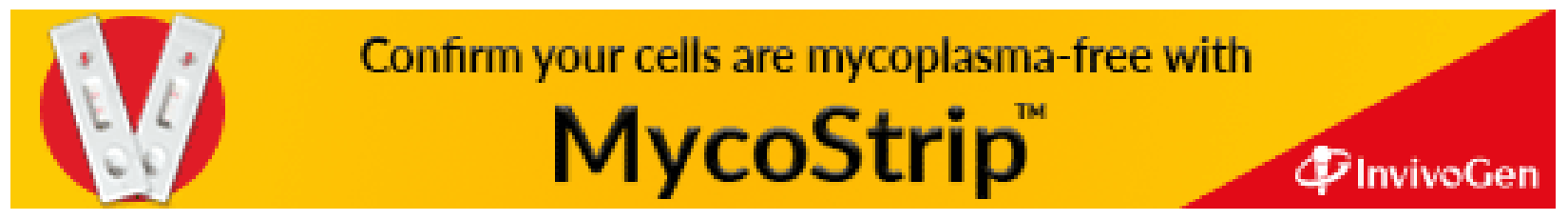

